\title{
Ilmu Pengetahuan dan Teknologi Dinasti Abbasiyah Periode Pertama
}

\author{
Vita Ery Oktaviyani \\ Mahasiswa Jurusan Sejarah Kebudayaan Islam, Fakultas Interdiciplinary \\ Islamic Studies, Program Pascasarjana, UIN Sunan Kalijaga, Yogyakarta \\ vita_ery@yahoo.com
}

\begin{abstract}
As a large dynasty Abbasid is very important to learn, considering at that time Islamic civilization experience the peak of glory. Science and technology have developed rapidly, especially in the first period. Therefore in this paper will be discussed several things around the dynasties ranging from a brief history of the Abbasid dynasty as well as Science and Technology what is growing.
\end{abstract}

Keywords:Abbasid Dynasty, Science and Technology of the Abbasid Dynasty, the Triumph of Islam.

\begin{abstract}
Abstrak
Sebagai dinasti yang besar Abbasiyah sangat penting untuk dipelajari, mengingat pada masa itu peradaban Islam mengalami puncak kejayaan. Ilmu pengetahuan dan teknologi mengalami perkembangan yang pesat terutama pada periode pertama. Oleh karena itu dalam tulisan ini akan dibahas beberapa hal seputar dinasti tersebut mulai dari sejarah singkat Dinasti Abbasiyah serta Ilmu Pengetahuan dan Teknologi apa saja yang berkembang.
\end{abstract}

Kata Kunci:Dinasti Abbasiyah, Ilmu Pengetahuan dan Teknologi Dinasti Abbasiyah, Kejayaan Islam.

\section{PENDAHULUAN}

Peradaban Islam mengalami puncak kejayaan pada masa Dinasti Abbasiyah. Perkembangan ilmu pengetahuan sangat maju, diawali dengan penerjemahan naskah asing terutama Yunani ke dalam bahasa Arab. Pendirian pusat pengembangan ilmu dan perpustakaan Bait Al-Hikmah dan terbentuk mahzab ilmu pengetahuan dan keagamaan sebagai buah kebebasan berpikir. Kemajuan peradaban Abbasiyah disebabkan stabilitas politik dan kemakmuran ekonomi kerajaan. Para penerjemah tidak hanya dari kalangan Islam, namun juga pemeluk Nasrani (Syiria) dan Majusi (Persia). Naskah Yunani diterjemahkan

${ }^{1}$ Siti Maryam, Sejarah Peradaban Islam: Dari Masa Klasik Hingga Modern, cet ke-4(Yogyakarta: Lesfi, 2012), h. 97. 
dalam bahasa Syiria Kuno lalu dalam bahasa Arab. Hal ini karena penerjemah pendeta Kristen Syiria hanya memahami bahasa Yunani. Kemudian ilmuan berbahasa Syiria dan Arab menerjemahkan ke dalam bahasa Arab. Pelopor penerjemahan Khalifah Abu Ja far Al Manshur. Dunia Islam pada waktu itu dalam keadaan maju, jaya, makmur sebaliknya dunia Barat masih dalam kegelapan, bodoh dan primitif. ${ }^{2}$

Pada masa tersebut dikenal ahli agama antara lain Imam Syafi'i yang pernah mengajar fiqh di Baqdad. Imam Abu Hanifah, Imam Malik dan Imam Syafi i menolak menjadi Qadi Dinasti Abbasiyah. ${ }^{3}$ Selain itu juga banyak muncul tokoh dalam bidang keilmuan masing-masing misalnya: Yahya ibn Haris, Hamzah ibn Habib, Abu Abdurrahman Al Muqri, Khalaf ibn Hisyam, Abdullah ibn Abbas, Muqatil ibn Sulaiman, Muhammad ibn Ishak, Imam Muslim, Ibnu Muqaffa dll. Adanya tokoh-tokoh intelektual menjadi bukti konkret kemajuan Islam yang identik dengan The Golden Age. ${ }^{4}$

\section{HASIL DAN PEMBAHASAN}

Dalam tulisan ini akan dibahas tiga hal mengenai Dinasti Abbasiyah, yaitu: seperti apa sejarah singkat Dinasti Abbasiyah, bagaimana Perkembangan Ilmu Pengetahuan pada masa Dinasti Abbasiyah dan sejauh mana Perkembangan Teknologi Dinasti Abbasiyah.

\section{A. Sekilas Tentang Dinasti Abbasiyah}

1. Sejarah Berdirinya Dinasti Abbasiyah

Berdirinya Dinasti Abbasiyah tidak lepas dari peran Abu Muslim AlKhurasani, di tangannya pecahlah revolusi terbesar dalam sejarah Islam, dengan tumbangnya Dinasti Ummayah. Ahli sejarah Barat memanggilnya Great Revolution in Islam. 5 Pendiri Dinasti Abbasiyah adalah Abdullah AlSaffah ibn Muhammad ibn Ali ibn Abdullah ibn Al-Abass. Kekuasaannya berlangsung 132-656 $\mathrm{H}$ atau 750-656 M. Pada mulanya, ibu kota negara adalah Al-Hasyimiyah, dekat Kufah. Tahun 762 M untuk lebih memantapkan dan menjaga stabilitas negara Abu Ja'far Al-Manshur memindahkan ibu kota ke Bagdad, dekat bekas ibu kota Persia, Ctesipon. Dengan demikian, pusat pemerintahan dinasti Bani Abbas berada di tengah-tengah bangsa Persia.

2. Periode Pertama Dinasti Abbasiyah

Periode pertama (132-232 H/750-847 M), pemerintahan mencapai masa keemasan. Secara politis para khalifah merupakan tokoh kuat dalam

\footnotetext{
${ }^{2}$ Musyrifah Sunanto, Sejarah Islam Klasik:Perkembangan Ilmu Pengetahuan Islam (Jakarta: Kencana, 2003), h. 54.

${ }^{3}$ Jamil Ahmad, Seratus Muslim Terkemuka terj. Hundred Great Muslims (Jakarta: Pustaka Firdaus, 1996), h. 89.

${ }^{4}$ Istianah Abu Bakar, Sejarah Peradaban Islam: untuk Perguruan Tinggi Islam dan Umum (Malang: UIN-Malang Press), h. 84.

${ }^{5}$ Joesoef Sou`yb, Sejarah Daulat Abbasiah (Jakarta: Bulan Bintang, 1977), I: 10-14.
} 
politik dan agama, sehingga kemakmuran rakyat meningkat. Periode ini berhasil menyiapkan landasan bagi perkembangan filsafat dan ilmu pengetahuan Islam. Setelah periode ini berakhir, pemerintahan Dinasti Abbasiyah mulai menurun dalam bidang politik, meskipun filsafat dan ilmu pengetahuan terus berkembang. ${ }^{6}$

Khalifah Abu Al-Abass (132-136 H/749-754 M ), menyebut dirinya al-Saffah, ${ }^{7}$ penumpah darah, yang kemudian menjadi julukannya. Saudaranya yang juga penerusnya, Abu Ja`far (136-158 H/754-775 M), mendapat julukan al-Manshur. ${ }^{8}$ Dasar-dasar pemerintahan diletakkan dan dibangun oleh Abu Al-Abbas dan Abu Ja'far Al Manshur, puncak keemasan berada pada khalifah sesudahnya, yaitu Al-Mahdi (158-169 H/775-785 M), Al-Hadi (169-170 H/785-786 M), Harun Al-Rasyid (170-193 H/786-809 M), Al-Ma`mun (198-201 H/813-817 M), Al-Mu`tashim (218227 H/833-842 M ), Al-Wasiq (227-232 H/842-847 M), dan Al-Mutawakkil (232-247 H/847-861 M). ${ }^{9}$

3. Pembentuk Peradaban Dinasti Abbasiyah

Kemenangan tentara Islam masa Al-Mahdi dan Harun Al-Rasyid atas Bizantium, memunculkan gerakan intelektual dalam sejarah Islam. Setelah tercapai kemenangan dalam peperangan, para tentara membuka jalan bagi bidang pemerintahan, keuangan, undang-undang dan ilmu pengetahuan untuk berkarya di bidangnya. Dengan demikian maka muncul penyair, filsuf, ahli sejarah, ahli ilmu hisab, tokoh agama dan pujangga yang memperkaya khazanah bahasa Arab. ${ }^{10}$ Disebabkan masuknya pengaruh asing, yaitu; Yunani, Suriah, India, Persia dan Yahudi. Gerakan intelektual ditandai dengan proyek penerjemahan karyakarya berbahasa Persia, Sanskerta, Suriah (aramaik) dan Yunani ke dalam bahasa Arab.

Beberapa pengaruh yang diperoleh Dinasti Abbasiyah antara lain: Yunani, India, Persia dan Yahudi. Pengaruh peradaban Yunani dalam filsafat dan logika. Yunani juga mempengaruhi ilmu kedokteran, teknik, mekanik, kimia dll.11 Penerjemah pertama bahasa Yunani adalah Abu Yahya ibn Al-Bathriq, yang menerjemahkan karya Galen dan Hippocrates (436 S.M) dalam bidang kedokteran. Selain itu ada karya Ptolemius (Quadripartitum) dan karya Euchid (Almagest), tentang astronomi. Peradaban India berpengaruh dalam ilmu matematika, dan kedokteran terutama ilmu perbintangan. India menjadi sumber inspirasi pertama dalam bidang mistisisme dan matematika. Peradaban Persia mewarnai

\footnotetext{
6 Badri Yatim, Sejarah Peradaban Islam : Dirasah Islamiyah (Jakarta: PT Raja Grafindo Persada, 2004), II: 49-51.

7 Philip K. Hitti, History of The Arabs (Jakarta : Serambi, 2002), h. 358.

8Ibid., h. 360.

${ }^{9}$ Badri Yatim, Sejarah, h. 52.

${ }^{10}$ Ahmad Syalabi, Sejarah dan Kebudayaan Islam (Jakarta: Pustaka Al Husna, 1993), III: 185-186.

11 Yusuf Al-Isy, Dinasti Abbasiyah (Jakarta : Pustaka Al-Kautsar, 2014), h. 255.
} 
sastra Arab. Khalifah Abbasiyah meneliti sejarah raja-raja Persia dan mengikuti administrasi mereka. Karya terjemahan lain dari bahasa Persia oleh Al-Fadhl ibn Nawbakhti ( $815 \mathrm{M})$ kepada lembaga pustaka Harun AlRasyid. Kesenian, kaligrafi atau seni menulis indah (belles-letters). Dalam bidang sastra Ibn Al Muqaffa menerjemahkan Kalilah Wa Dimnah dari bahasa Pahlevi dan menerjemahkan buku As-Sind Wa Al-Hind. Yahudi berpengaruh dalam kisah Taurat dan tafsir Talmud. Para mufassir menerima cerita, sehingga diantara mereka ada yang berlebihan hingga disusupi kisah israiliyyat. Diantara umat Islam ada yang terpengaruh pemikiran Yahudi tentang sifat Allah yaitu tentang penyerupaan (tasybih) dan mencari tentang sifat Allah akhirnya beralih kepada pemikiran bahwa Al-Qur'an adalah makhluk. ${ }^{12}$ Terlihat dalam sastra dan syair, muncul pengaruh tentang kerahiban dalam ucapan-ucapan sebagian penyair dan aliran-aliran tasawuf.

\section{B. Ilmu Pengetahuan Dinasti Abbasiyah}

1. Bangsa yang Peduli Pada Ilmu Pengetahuan

Pada awalnya ilmu pengetahuan berasal dari Al-Qur`an dan hadits. Orang Islam keturunan non Arab khususnya orang-orang Persia berpendapat bahwa mereka merasa perlu mempelajari tata bahasa Arab (nahwu) dan philologi serta syair-syair sebelum Islam yang memerlukan studi geneologi dan history untuk memahami Al-Qur`an dan hadits. ${ }^{13} \mathrm{Hal}$ yang menarik peneliti sejarah kebudayaan Islam bahwa mayoritas orang yang fokus pada keilmuan adalah kaum Mawali terutama orang Persia. Bahasa Arab merupakan satu-satunya media komunikasi untuk berinteraksi dengan sesama muslimin di Abbasiyah. Mayoritas pembawa ilmu dalam Islam adalah orang asing (non Arab), baik ilmu syar ‘ maupun ilmu aqli. Sangat langka dari kalangan bangsa Arab, bila ada orang Arab dalam nasabnya, namun bahasanya bukan Arab termasuk pendidik dan gurunya. ${ }^{14}$ Orang Persia biasanya tinggal di kota-kota besar, mereka berdagang dan sudah lama mengenal seni kebudayaan.

Pada mulanya umat Islam tidak mempunyai ilmu tentang seni dan ilmu pengetahuan lain. Seluruh perhatian mereka hanya melekat pada undang-undang Al-Qur`an dan hadits. Mereka tidak tau cara mengajarkan ilmu, seni (adab), mengarang, menyusun atau mengumpulkan buku. Mereka mampu mengulangi Al-Qur’an dan meriwayatkan hadits. Pemindahan ilmu pengetahuan dilakukan secara lisan. Seiring berjalannya waktu ilmu-ilmu yang disampaikan secara lisan, dan dihafalkan mengalami pengurangan saat disampaikan pada generasi

\footnotetext{
12 Ibid., hlm. 255-256. Ahmad Syalabi, Sejarah dan Kebudayaan Islam (Jakarta: Pustaka Al Husna, 1993), III: 185-186.

13 Hasan Ibrahim Hassan, Sejarah dan Kebudayaan Islam terj. Islamic History and Culture (Yogyakarta: Depag RI IAIN SUKA, 1989), h. 130-131.

${ }^{14}$ Hasan Ibrahim Hasan, Sejarah dan Kebudayaan Islam (Jakarta : Kalam Mulia, 2013), III: 383.
} 
selanjutnya. Hal ini membuat penyelamatan ilmu sangat diperlukan untuk mencegah kehilangan maka dilakukan penulisan.

\section{Gerakan Penerjemahan}

Ketika pemerintahan sudah kokoh Khalifah Abbasiyah khususnya Abu Ja`far Al Manshur, Harun Al-Rasyid, dan Al-Ma`mun menaruh perhatian khusus pada ilmu pengetahuan. Mereka mengirim misi ke Konstantinopel untuk membawa hasil ilmiah bidang filsafat, logika, kedokteran, matematika, astrologi (ilmu perbintangan), musik, geografi dan sejarah. Al Ma`mun meminta buku pengetahuan kuno dari Raja Romawi dan memerintahkan menerjemahkan karya tersebut dalam bahasa Arab.

Hasil karya lain dari bahasa Assyria (bahasa Persia Kuno) dan Sanskerta (bahasa India Kuno) diterjemahkan dalam bahasa Arab. Para sarjana yang menerjemahkan karya Persia yaitu: keluarga Nubacht, Hasan ibn Sahal, Wazir besar Ma`mun dan Baladhuri pengarang Futuh al-Buldan. Selain dewan penerjemah pemerintah, rakyat yang kaya ikut melindungi penerjemahan. Sebagai hasil dari kebangkitan ini, banyak sarjana yang mulai mempelajari, mengomentari dan merevisi buku penerjemah lain. Selama pemerintahan Dinasti Abbasiyah Pertama ada empat penerjemah terkemuka yaitu Hunayn ibn Ishaq, Wa qub ibn Ishaq (dari suku arah Kinda), Thabit ibn Qurra (dari Harran) dan Umar ibn Al-Farrakhan (dari Tabaristan). ${ }^{15}$

3. Perpustakaan Bait Al-Hikmah dan Darul Hikmah Sebagai Pusat Kebudayaan Islam Dinasti Abbasiyah

Bait Al-Hikmah merupakan kelanjutan institus Jundishapur Academy di masa Imperium Sasania Persia didirikan oleh Harun Al-Rasyid. Perpustakaan ini dilengkapi berbagai buku karangan Al-Ma`mun. Perpustakaan ini menyimpan karya ilmiah dalam bidang agama dan mampu bertahan hingga penyerbuan bangsa Mongol. Perpustakaan Bait Al-Hikmah dan Darul Hikmah, mencapai puncaknya pada masa Khalifah Al-Ma`mun. Perpustakaan ini lebih menyerupai universitas di mana terdapat kitab-kitab secara lengkap.

Orang-orang datang ke perpustakaan untuk membaca, menulis dan berdiskusi. Di samping itu perpustakaan ini juga berfungsi sebagai kantor penerjemahan, terutama karya kedokteran, filsafat, matematika, kimia, astronomi dan ilmu alam. ${ }^{16}$ Ahli ilmu pengetahuan dan sastra yang sering mengunjungi perpustakaan ini mempunyai efek yang besar dalam kemajuan aktifitas ilmiah selama pemerintahan Dinasti Abbasiyah seperti halnya dalam penyebaran di antara umat Islam dan non Islam. Dalam perkembangan selanjutnya, para ilmuan Islam telah mengembangkan ilmu-ilmu yang diterjemahkan dan mendapatkan temuan ilmiah baru.

${ }^{15}$ Hasan Ibrahim, Sejarah, (1989), h. 133-134.

16 Dewan Redaksi Ensiklopedi Islam, “Ensiklopesi Islam" (Jakarta: PT Intermesa: 1993), I: 7. 
Disini letak sumbangan Islam tehadap ilmu dan peradaban Barat atau dunia. ${ }^{17}$ Perlindungan terhadap ilmu pengetahuan tidak terbatas pada khalifah-khalifah saja, namun juga menjadi urusan wazir (menteri) dan para pejabat tinggi. Beberapa diantara mereka sering mengadakan pertemuan-pertemuan ilmiah di rumah mereka. ${ }^{18}$

4. Pembagian Ilmu

Penulis muslimin membedakan ilmu menjadi dua yaitu : ilmu naql (syara) dan ilmu akal (ilmu hikmah).

a. Ilmu Naql

Ilmu Naql adalah ilmu yang berhubungan dengan Al-Qur'an, mencakup: ilmu qiraat, tafsir, ilmu hadits, fiqh, ilmu kalam, nahwu, bahasa, bayan dan adab (kesusastraan).

1) Ilmu Qiraat

Ilmu qiraat dianggap fase awal dan cikal bakal tafsir Al-Qur'an. Penyebab terjadinya beragam qiraat menjadi tujuh. Ahli qiraat yang terkenal:Yahya ibn Haris Az Zamari, Hamzah ibn Habib Az Zayyat, Abu Abdurrahman Al Muqri dan Khalaf ibn Hisyam Al Bazzar.

2) Tafsir

Ahli tafsir dalam menafsirkan Al-Qur'an berorientasi pada dua arah yaitu: at tafsir bi al ma`sur dan at tafsir bi ar ra`yi. Seiring berjalannya waktu at tafsir bi al ma`sur menerima pendapat ahli kitab yang masuk Islam, yaitu pendapat dari Taurat dan Injil. Ahli tafsir yang terkenal adalah Abdullah ibn Abbas, Muqatil ibn Sulaiman Al Azadi, Muhammad ibn Ishak, Jarir At Tabari. Pada masa ini muncul kelompok Mu'tazilah (para pemikir bebas), mereka pendapatnya bersandar pada akal. Dalam memerangi kelompok ini didirikan pendidikan yang berasaskan Al-Qur`an dan membuat dalil yang mematahkan dalil musuh yang terambil dari Al-Qur`an melalui tafsir.

3) Hadits

Bangsa Arab baru membukukan hadits sejak abad kedua hijriyah. Sehingga lahir ulama hadits antara lain: Imam Malik, Imam Bukhari, Imam Muslim, pengarang Sahih Bukhari-Muslim. Kemudian muncul Abu Daud, pengarang kitab As Sunan, At Tirmizi, pengarang kitab Al Jami', An Nasa $i$ dan Ibnu Majah keduanya pengarang kitab As Sunan dengan nama Al Kutub As Sittah.

${ }^{17}$ Ibid., I:7.

${ }^{18}$ Hasan Ibrahim, Sejarah, (1989), h. 133. 


\section{4) Fiqh}

Diantara ahli fiqh masa ini adalah Imam Malik ibn Anas, mengarang kitab Al Muwata', Al Mudawwanah. Ahmad ibn Hambal, Imam Syafi i, Abu Hanifah, Al Lais ibn Sa`d, Abu Yusuf, karyanya berupa Kitab Al Kharraj (disusun atas permintaan Khalifah Harun Al-Rasyid). Kitab ini memuat urusan keuangan negara yang hanya dikuasai oleh pejabat seperti Abu Yusuf dan berada dekat dari khalifah serta menguasai fiqh.

5) Ilmu Kalam

Ilmu kalam dirangkai berdasarkan logika, terutama dalam hal yang berhubungan dengan akidah. Orang yang fokus dalam ilmu ini disebut mutakallimun. Pada awalnya mutakallimun ditujukan kepada orang yang fokus pada akidah keagamaaan, namun selanjutnya ditujukan kepada yang menyalahi Mu'tazilah dan menjadi pengikut Ahlu Sunnah Wal Jamaah. Ahli ilmu kalam terkemuka adalah Wasil ibn Ata, Abu Huzail Al `Allaf, An Nizam, Abu Hasan Al Asy`arid an Hujjatul Islam Imam Gazali.

6) Ilmu Nahwu

Ahli ilmu nahwu Basrah disebut "ahli logika". Diantara ilmuan itu adalah Al-Asma i dan Abu Ubaidah, Al-Mubarrad pengarang kitab Al Kamil.

7) Kesusastraan

a) Syair

Penyair Abbasiyah yang terkenal adalah Abu Nawas, dengan syairnya tentang arak, asrama, berburu dan ragam obyek syair lainnya sejalan dengan kebudayaan dan kemewahan yang tersebar masa itu. Kehidupan penyair tergantung kedekatan pada khalifah dan pembesar negara, oleh karena itu syair sanjungan menjadi ciri utama syair masa ini.

b) Prosa

Abdullah ibn Al Muqaffa menerjemahkan buku Pahlevi (Persia Kuno). Diantaranya Kalilah Wa Dimnah dalam bahasa sanskerta. Ini dianggap sebagai buku prosa tertua sastra Arab, tinggi susunan kalimat dan ungkapan. Pujangga masa ini, Abdul Hamid Al Katib, melakukan hal baru dalam menulis surat di awal surat ada pujian, pembagian paragraf dan pasal, penutup surat, termasuk muatan surat yang panjang lebar berkenaan dengan raja dan politik.

b. Ilmu Aql

Ilmu aql adalah ilmu yang diambil orang Arab dari bangsa non Arab. Ilmu aql mencakup : geografi, matematika, astronomi, kimia, filsafat, 
sihir, sejarah, teknik, ilmu astrologi, musik, kedokteran dan seni arsitektur.

1. Geografi (ilmu bumi)

Perluasan wilayah dagang mendorongnya menulis untuk menerangkan apa yang dialami. Tokohnya Ibn Khurdadbih menulis Kitab al-Masalik. Buku ini merupakan petunjuk resmi dan hasil karya geografi tertua dalam bahasa Arab. ${ }^{19}$ Ibn Khardazabah, mengarang Al Masalik Wa Al Mamalik.

2. Matematika dan astrologi

Pithagoras merupakan guru bangsa Arab dalam bidang matematika, menurutnya seseorang tidak akan menjadi filosof dan dokter yang baik tanpa mempelajari matematika. Dalam ilmu hitung terkenal Imran ibn Al Wadhdhah dan Shihab ibn Kasir. Astrologi sangat dibutuhkan, contohnya saat pembangunan kota Bagdad. Serta pemilihan waktu untuk membai at Ali Ar Rida. Ahlinya Al-Haris dan Ja`far ibn Umar Al Balkhi, penulis Isbat Al'Ulum dan Haiah Al Falak.

3. Astronomi

Ibn Ma`shar awalnya ahli hadits, kemudian mempelajari astronomi dan setelah 47 tahun berhasil membuat karya.

4. Kimia

Jabir ibn Hayyan (ahli kimia), adalah orang Tarsus di Eropa terkenal dengan nama Gaber. Ia banyak menulis buku kimia, pertambangan dan batu-batuan yang bermanfaat bagi Eropa.

5. Filsafat

Pada periode ini ide Yunani memasuki pemikiran Islam. Beberapa filsuf Islam karyanya diterjemahkan dalam bahasa Latin. Tokoh pertama yang mengenalkan filsafat Yunani ke dalam dunia Islam adalah Al-Kindi. Teologi Al-Kindi dekat dengan kaum Mu tazilah sehingga disukai Khalifah Al-Ma`mun, Al-Mu`tasim dan AlWatsiq. Setelah kebijakan di bawah Al-Mutawakkil ia mengalami penderitaan, bahkan perpustakaannya pernah disita walaupun pada akhirnya dikembalikan. ${ }^{20}$

6. Sejarah

Ibn Muqaffa menerjemahkan Kitab Khuday Nameh (Kitab Al Muluk) dari bahasa Pahlevi ke dalam bahasa Arab, dan dinamai Siyar Muluk Al `Ajm. Buku ini dianggap contoh buku sejarah

${ }^{19} \mathrm{Ibid} .$, h. 135-136.

${ }^{20}$ W. Montgomery Watt, Kejayaan Islam : Kajian Kritis dari Tokoh Orientalis terj. The Majesty That Was Islam (Yogyakarta: PT Tiara Wacana Yogya: 1990), h. 140-141. 
dikalangan bangsa Arab. Hisyam ibn Muhammad Al Kalbi (wafat $204 \mathrm{H}$ ) dan ayahnya adalah orang pertama bangsa Arab yang menulis dalam ilmu sejarah.

\section{Teknologi Dinasti Abbasiyah}

\section{Bidang Kedokteran}

Khalifah Abu Ja'far Al-Manshur saat sakit perut memanggil Ibn Bakhtisyu seorang kepala rumah sakit Jundisyapur penganut Kristen Nestor. Pada masa Harun Al-Rasyid Ibn Bakhtisyu mahir ilmu jiwa dalam menentukan penyakit neurotis serta pengobatannya. Pada masa Al-Mu'tashim terkenal Yahya ibn Masuwaih sebagai dokter. Para khalifah Abbasiyah bergantung pada dokter Irak, India dan Yunani. Pada masa Khlifah Al-Watsiq terkenal dokter Ibn Bakhtisyu, Ibn Musawaih, Mikhail dan Hunyn ibn Ishaq. Khalifah Al-Watsiq (227-232 $\mathrm{H} / 842-847 \mathrm{M}){ }^{21}$ meminta seorang dokter yang beragama Nasrani Hunayn ibn Ishaq menyusun sebuah buku, yang menerangkan tentang perbedaan makanan, obat, laktasit, anatomi tubuh, racun dan obat pelunturnya. Hunayn menulis buku The Book of Physical Cases. ${ }^{22}$ Para dokter masa ini menerangkan tentang mulut dan gigi, jenis, jumlah dan kegunaan masing-masing. Koehen Al Attar Al Yahudi (ahli farmasi), menyusun buku Sinahiah As Saidalah yang secara rinci mengemukakan obat-obatan serta menjelaskan cara membuat obat yang diminum, ditelan, berbentuk serbuk dan tablet.

\section{Seni dan Arsitetur}

Seni dekor mengalami kemajuan pesat, pada masa Abu Ja far AlManshur. Dekorasi kubah dari emas dan di atasnya terdapat patung yang bisa berputar jika tertiup angin. Al-Manshur suka beristirahat, jika ingin melihat air ia duduk di kubah Pintu Gerbang Khurasan, bila ingin melihat kawasan sekitar Bagdad ia duduk di Pintu Gerbang Syam. Bila ingin melihat Al Kurkh ia duduk di Pintu Gerbang Basrah dan jika ingin melihat perkebunan dan pertanian ia duduk di kubah Pintu Gerbang Kufah.

Pada masa ini istana-istana menjadi media menuangkan lukisan dan dekorasi, baik di bagian dalam maupun luar. Dekorasi dari bahan gibs, ditutup dengan gordyn berhiaskan lukisan khas Persia. Ciri dekorasi masa ini adalah dekorasi yang terbuat dari bahan gibs yang menutup bagian bawah dinding istana-istana, seperti ditemukan oleh para penggali reruntuhan kota Samara. Gambar-gambar ditemukan pada reruntuhan berupa binatang, burung dan manusia yang sedang berburu atau perempuan yang sedang menari. Gaya Abbasiyah dalam

${ }^{21}$ G.E Bosworth, Dinasti-Dinasti Islam terj. The Islamic Dynasties (Bandung: Mizan, 1993), h. 27.

${ }^{22}$ Hasan Ibrahim, Sejarah, (1989), h. 136-138. 
seni dekor tekstil, benda-benda antik dari logam dan keramik serta kayu telah menyebar di negara Islam pada waktu itu, hingga sampai Mesir, Afrika dan Iran. Dalam teknik terkenal Al Hajjaj bin Ar Ta`ah yang membuat kaligrafi Masjid Raya Bagdad pada masa Abu Ja 'far Al Manshur. Bahkan Baqdad dijuluki sebagai menara ilmu dan pengetahuan. ${ }^{23}$

\section{PENUTUP}

Perkembangan intelektual Dinasti Abbasiyah terlihat dengan terbentuknya jaringan keilmuan yang kuat terutama berhubungan dengan dua sumber agama yaitu Al-Qur'an dan hadits. Semuanya tidak luput dari pengaruh Yunani, India, Persia, Yahudi dan Nasrani.

Kekuasaan Islam Dinasti Abbasiyah mampu mengembangkan lembagalembaga ilmu pengetahuan dan seni arsitektur tinggi. Hal ini tidak akan pernah tercapai tanpa kondisi politik yang kondusif dan perekonomian yang stabil. Hal penting lainnya masa tersebut ada masa dimana banyak pemikir yang mempunyai kemauan keras untuk belajar dan mengembangkan diri, sehingga mampu menjadi pelopor ilmu pengetahuan. Ini ini juga karena adanya dukungan para khalifah dimasa itu yang cinta ilmu pengetahuan. Pengembangan ilmu pengetahuan tidak hanya menjadi tanggungjawab khalifah saja, namun juga menjadi urusan wazir (menteri) dan para pejabat tinggi. Beberapa diantara mereka sering mengadakan pertemuan-pertemuan ilmiah di rumah mereka.

\section{DAFTAR PUSTAKA}

Abu Bakar, Istianah, Sejarah Peradaban Islam: untuk Perguruan Tinggi Islam dan Umum, Malang: UIN-Malang Press.

Ahmad, Jamil, Seratus Muslim Terkemuka, terj. Tim Penerjemah Pustaka Firdaus, Jakarta: Pustaka Firdaus, 1996.

Al'Ilm, Dar, Atlas Sejarah Islam: Sejak Masa Permulaan hingga Kejayaan Islam, Jakarta: Kaysa Media, 2013.

Al-Isy, Yusuf, Dinasti Abbasiyah, Jakarta : Pustaka Al-Kautsar, 2014.

Dewan Redaksi Ensiklopedi Islam, Ensiklopesi Islam Jilid I, Jakarta: PT Intermesa: 1993.

Hassan Ibrahim, Hassan, Sejarah dan Kebudayaan Islam diterjemahkan dari Islamic History and Culture oleh Djahdan Humam Saleh, Yogyakarta: Depag RI IAIN SUKA, 1989.

Sejarah dan Kebudayaan Islam Jilid 3, diterjemahkan dari Tarikh al-Islam as-Siyasi wa add dini wa as saqafi wa alijtima $i$ oleh Aceng Bahauddin, Jakarta : Kalam Mulia, 2013.

${ }^{23}$ Dar Al-'Ilm, Atlas Sejarah Islam: Sejak Masa Permulaan hingga Kejayaan Islam (Jakarta: Kaysa Media, 2013), h. 89. 
G. E Bosworth, Dinasti-Dinasti Islam diterjemahkan dari The Islamic Dynasties oleh Ilyas Hasan, Bandung: Mizan, 1993.

Maryam dkk, Siti. Sejarah Peradaban Islam: Dari Masa Klasik Hingga Modern, Yogyakarta: Lesfi, 2012.

Philip K. Hitti, History of The Arabs, terj. R. Cecep Lukman Yasin dan Dedi Slamet Riyadi, Jakarta : Serambi, 2002.

Syalabi, Ahmad, Sejarah dan Kebudayaan Islam Jilid 3, terj.Muhammad Labib Ahmad , Jakarta: Pustaka Al Husna, 1993.

Sou yb, Joesoef, Sejarah Daulat Abbasiah I, Jakarta: Bulan Bintang, 1977.

Sunanto, Musyrifah, Sejarah Islam Klasik:Perkembangan Ilmu Pengetahuan Islam, Jakarta: Kencana, 2003.

W. Montgomery Watt, Kejayaan Islam : Kajian Kritis dari Tokoh Orientalis diterjemahkan dari The Majesty That Was Islam oleh Hartono Hadikusumo, Yogyakarta: PT Tiara Wacana Yogya: 1990.

Yatim, Badri, Sejarah Peradaban Islam : Dirasah Islamiyah II, Jakarta: PT Raja Grafindo Persada, 2004. 